\title{
The Impact of Atmospherics on Service Quality: A Study on The Hotel Industry in Mangalore
}

\author{
Mrs. Reema Agnes, Frank Assistant Professor, Department of Business Administration, Alva's \\ Institute of Engineering and Technology, Moodbidri. \\ Phone:8150021686,Email: Reemafrank@yahoo.co.in \\ Mr. Melvin Dsouza, Assistant Professor, Srinivas College of Hotel Management, Manalore \\ Email:melvindsouza19@yahoo.co.in
}

\begin{abstract}

Key Words: Service
quality, customer
satisfaction,
atmospherics.
\end{abstract}

\section{INTRODUCTION}

Service sector turned out to be a biggest contributor to Indian economy. The Indian hospitality industry has recorded healthy growth fuelled by robust inflow of foreign tourists as well as increased tourist movement within the country and it has become one of the leading players in the global industry. The World Travel \& Tourism Council calculated that in 2012 the tourism industry generated INR6.4 trillion or $6.6 \%$ of the nation's GDP. It supported 39.5 million jobs, 7.7\% of its total employment. So the service organizations will compete with each other to deliver the best to its customers in order to achieve customer delight. Hotel industry acts as an important part of the service sector, plays a role of a home away from home for its customers. Hotel sector in India is at the boom stage as the number of tourist increasing year by year and also the domestic tourist (Ministry of tourism, Govt of India, 2012).

A customer's expectation of a particular service is determined by factors such as recommendations, personal needs and past experiences. The expected service and the perceived service sometimes may not be equal, thus leaving a gap. Customers generally have a tendency to compare the service they experience with the service that they expect. If the experiences do not match the expectations, there arises a gap. Ten determinants that may influence the appearance of a gap were described by Parasurama, Zeithmal and Berry (1985) in the SERVQUAL model with five dimensions tangibility, reliability, responsiveness, service assurance, empathy.

Mangalore officially called as Mangaluru, is the 
second largest city in the Karnataka State, growing as a business hub. Mangaluru is very famous for its coastal cuisine, has got many hotels of the international standards. Due to its natural beauty and religious relationships a huge number of tourists are attracted towards this city. Hence it is very necessary to have best service quality amongst the hotel industry to attract more and more consumers towards it.

\section{OBJECTIVES OF THE STUDY:}

1. To assess the factors affecting the service quality of hotels in Mangalore.

2. To analyze the impact of atmospherics on the service quality.

3. To suggest the relevant improvements on the service quality through the study.

\section{LITERATURE REVIEW:}

The service quality plays a crucial role in customer satisfaction and retention of employees (Amjad, et.al 2011). Parasuraman and Berry (1988) proposed an empirically derived method called SERVQUAL to be used by hotel industry to improve quality. Service quality in terms of both customers' expectation and customers' perception could lead to customer loyalty, enhanced image, reduced costs and increased business performance (Boon, Rompho, 2012). For this reason, one of the most important factors affecting hotel business performance is the improvement of service quality, which is important for creating financial benefit leading to a long-term competitive advantage for the hotel. To face the competition the hotel business is seeking new tools to create competitive advantages.
The further research in the similar area proved that the atmospherics of a hotel will have a direct impact on the hotel service quality. So there could be a factor called as hotel atmospherics and the improvement in this area would give a competitive advantage to the organizations. Ogle (2009), in his study concluded that the lighting is an important factor in the hotel and creates a good ambience. A customer who is comfortable in the environment will be more likely to have a positive experience on the hotel. Lighting will help to create the desired mood and felling to support the hotels brand. The front desk personal to appear neat and clean, reasonable pricing and environment location will play a significant role in customer satisfaction (Abbasi, 2010).

According to Naseem, et.al (2011), the improvement of hotel service quality in Pakistan is directly influenced by impression of the reception hall, cleanliness, atmospherics of the hotel, courtesy of the employees, guest room comfort, etc. The study also showed that impact of service quality affects the customer satisfaction that results in success of hotel. Petzer Mackay (2014), supported the previous studies and confirmed that in order to retain the customer the food and service quality and the dining atmospherics should be maintained effectively. The service-scapes will impact on the behaviour of both customers as well as the employees (Mary Jo Bitner, 1992).

Naqshbandi, Munir,(2011) says that the atmospheric elements of hotel lobbies that influence a customer's impression and examines 
the influence of "openness" as one of the personality traits on customer's impression in Convention and Boutique hotels. The hotel industry creates a unique and differentiated design of lobby to attract costumers' attention and emotional appeal.

An appropriate physical environment helps produce quality performance. The design features that guests find most attractive in a hotel lobby, and thus, determine how these features affect their overall behavior toward the total hotel's environment. Customers may be affected by lighting, color, textures, the quality of materials, the style of furnishings, and wall décor. Seating comfort, the presence of a bar, and appropriate interior-scaping are additional commonly desired features that can play a significant role in overall client satisfaction (Thapa, Arch, 2007). Choosing the right color in hotel design long has gone beyond what looks vibrant or pretty. Color and surface design will help to attract more clients and send a message to the type of guest hotels wish to attract and make loyal customer (Baker, 2013).

The Hotel design is a result of socio-cultural changes, technological advancements, economic and political situations, and environmental factors. Those elements create the macroenvironment of hospitality business and strongly influence the customers' demands, wishes, and desires. Therefore, hotel properties and marketers need to carefully observe and evaluate those transformations in order to offer the "right product or services, to the right customer, at the right time for the right price". The micro-environment, which includes customers, employees, suppliers, intermediaries, competitors, and publics, has also an impact on hotel design but on a much smaller scale(Dr. Lund, Durlacher, 2011).

A good physical setting of a hotel evokes service experience and long lasting memories in the mind of the customers even after the consumption of such products and services. The management of the hotels should make the hotels more like homely environment in order to provide a harmonious and comfortable environment where guest can feel very much at home. When these are put in place, we can build, monitor, and improve so that customers will continue to patronize the industry.

\section{NEED FOR THE STUDY:}

Every hotel differs from the other based on the service provided like accommodation, food and beverage services, entertainment, recreation, communication, transportation, room service, laundry service, conference and meeting arrangements, first aid, etc. Also the hotel differs from the other based on the atmospherics such as lobby design, lighting moods, music, decoration, colour combination, fragrance etc which will have a impact on the customer experience. Hence the better ambience and atmospherics of a hotel would attract many customers as they feel comfortable and relaxed. Hence atmospherics plays a important role on customer satisfaction along with service quality. 
Service quality is an assessment of how well a delivered service conforms to the client's expectations (Business Directory). Hence every service organization especially hotels assess the service quality in order to find the significant difference between the service perception and expectation to know the level of customer satisfaction. A business with high service quality will meet customer needs whilst remaining economically competitive. Improved service quality may increase economic competitiveness. This aim may be achieved by understanding and improving operational processes, identifying problems quickly and systematically, introducing valid and reliable service performance measures and measuring customer satisfaction and other performance outcomes.

\section{RESEARCH METHODOLOGY:}

The research was conducted in the Mangalore region with 3 star hotels to analyse the impact of atmospherics on the service quality. The primary data was collected through the questionnaire method and 250 filled questionnaires were collected from the customers. The questionnaire consists of three parts namely, demographic data, service quality questionnaire using the Parasuraman, Zeithmal (1985) and the questions related to the atmospherics. The convenience sampling method was used in order to fetch the primary data.

\section{DATA ANALYSIS:}

The study consists of a total of 250 respondents from Mangalore city who are using the services of the hotels especially in the range of 3-star hotels. The demographic data consists of $42 \%$ of the respondents were male and $58 \%$ of the respondents were female customers. Majority $(72 \%)$ of the respondents were in the age group below 30 years, which concludes that majority of the youngsters visit the hotels and are unmarried (65\%). As per the monthly income $41 \%$ of the customers belong to the salary range of Rs 31,000 - Rs 40,000,36\% belong to the range of Rs 11,000 - Rs 20,000. Around 34\% of the respondents visit once in a week and also $34 \%$ of them visit once in a month. The respondents prefer their friends (43\%) and family (46\%) accompanying them to the hotels. There are several reasons that they visit a hotel are food quality (38\%), price (16\%), good ambience (16\%), Location advantage (10\%), availability of parking space (7\%), good interiors of the hotel (7\%), the availability of children play area $(6 \%)$ which tells us that the atmospherics factors are also quite important for a hotel, so that the customers can relax and enjoy their time.

The atmospherics factors such as physical facility, music played, pleasant odour, parking space, modern technical amenities, clear signage, interior design, illuminations, furnishing of the hotel, room temperature, etc were been studied and analysed.

The table shows the multivariate analysis of the impact of atmospherics on the service quality we found the following results. 


\begin{tabular}{|c|c|c|c|c|c|c|}
\hline \hline & Coefficients & Standard Error & t Stat & P-value & Lower 95\% & Upper 95\% \\
\hline Intercept & 0.67 & 0.16 & 4.07 & 0.00 & 0.34 & 0.99 \\
\hline Reliability (x1) & 0.11 & 0.05 & 2.26 & 0.02 & 0.01 & 0.21 \\
\hline Responsiveness(x2) & 0.09 & 0.07 & 1.30 & 0.20 & -0.05 & 0.22 \\
\hline Assurance (x3) & 0.01 & 0.07 & 0.13 & 0.89 & -0.12 & 0.14 \\
\hline Empathy (x4) & 0.02 & 0.05 & 0.46 & 0.65 & -0.08 & 0.13 \\
\hline Tangibility (x5) & 0.31 & 0.04 & 6.90 & 0.00 & 0.22 & 0.40 \\
\hline
\end{tabular}

From the above data, we could build the equation to depict the relationship between atmospherics and service quality as $\mathrm{Y}=0.67+0.11 \times 1+0.09 \times 2$ $+0.01 \times 3+0.02 \times 4+0.31 \times 5$ at $95 \%$ confidence level.

We could confirm that in order to improve the overall satisfaction of the hotel the dimensions such as responsiveness, assurance, empathy must be taken care of. The employees are major component in influencing the assurance, empathy and responsiveness as per Parasuraman and Zeithmal(1985).It clearly states us that the employee's plays a vital role in improving the service quality thus trained employees are important in order maintain a courteous relationship between the customer and the employees. Because all the three low scoring dimensions have direct relationship with the employees. Employees must have enough information about the hotel, food items availability, they must be patient enough to listen to the customers, must be courteous, in order to build the strong relationship with the customer, moreover employees must be trust worthy so that the customers feel safe in their transactions (Sharma, 2014). A satisfied customer will always be an asset to the organization thereby increasing its profitability.
Meanwhile we observed that reliability and the tangibility dimensions are in a better position which concludes customers do not have many concerns with the hotel management also the modern hotels equipped with good equipments and amenities.

When we study the data little more deeply the confidence level for responsiveness, assurance, empathy shows a negative value at 95\% confidence level. It says these are the critical factors need to be concentrated more in order to avoid customer dissatisfaction. A slight variations in the employee behaviour will show a high customer dissatisfaction, which will be a alarming truth for the hotels in the Mangalore city. Therefore more importance to be given while recruiting the candidates so as to see the right person at the right job. Proper training to be given to employees and employee career development programs etc would be beneficial which will show a positive result on the customer satisfaction. This follows the statement of the Top 5-star hotel, The Marriott's value statement 'you take care of your employees in turn they will take care of your customers'. Hence it would be an eye opener for the companies to invest more on human resources. 


\section{SUGGESTIONS:}

From the data analysis it was observed that responsiveness, empathy and assurance to be taken care of by the hotel industries in Mangalore by:

- Treating every guest as VIP and giving them utmost importance and care. "Feel at Home" should be the jargon followed by every hotelier.

- Personalized customer service will definitely improve the hotel performance and the technology can be linked towards it for better service.

- The employee trainings to be given priority and it should happen every day basis so that the quick modifications and quick correction of mistake can happen. This can ensure that the mistakes may not repeat and improve the customer delight.

\section{LIMITATIONS OFTHE STUDY:}

- The survey was carried out according to the convenience of the respondents.

- Collection of data and study was limited to 250 respondents due to time constraint.

- The data collected is limited and factual to some extent since some information could not be collected as they were confidential.

\section{CONCLUSION:}

The study opens our mind set towards the influence of atmospherics on service quality of hotels in Mangalore city which says there is a relationship between good atmospherics and improvement in service quality. Also it proves that in Mangalore city the hotels have modern facilities, infrastructure and the ambience of these are really good which shows the positive phase of the hotel industry. The quality of the service provide by the employees outweighs the need of investments in the atmospherics of the hotel. The implication is that the concept of quality remains largely attractive to the hotel industry as it allows the hotels to improve their image while bolstering the underlying profit making strategy. As long as the best practices remains, it will be easy to achieve the organization goals.

\section{BIBLIOGRAPHY:}

- Afshan Naseem, S. E. (2011), 'Improvement of Hotel Service Quality: An Empirical study," International Journal of Multidisciplinary Sciences and Engineering, PP 54-56.

- Amue Gonewa John K. A.(2013), Physical Settings and Patronage of Three Star Hotels in Nigeria's Federal Capital Territory Abuja," International Journal of Business Management Economics, Volume 4, Number 3, PP 738-744.

- Bapat Harish B., Soni Vishal, Khasgiwala Vishal (2015), 'A Study of Customer Satisfaction \& Service Quality of Indian Hotels (A Comparative Study in Indore Region)," IOSR Journal of Business and Management, Volume 17, Number 2, PP 53-60

- Batra Manika (2014), Analysing Service Quality of Five Star Hotels in National Capital Region from Customers Perspective," Apeejay - Journal of Management Sciences and Technology, volume 3, Number 1, PP 20 - 29

- Bitner, M. J. (1992), Servicescapes: The Impact of Physical Surroundings on Customers and Employees,"The Journal of Marketing , PP 57-71.

- Daniel Petzer, D. N. (2014), Dining atmospherics and food and service quality as predictors of customer satisfaction at sit-down hotels," African Journal of Hospitality, PP 1-14.

- Dhiraj Thapa, B. (2007), "Hotel Lobby Design: Study of Parameters of Attraction," Project submitted for the Texas University.

- Franz, J. (2003), Interior Design Criticism: Between Excess and Austerity,"IDEA Journal PP 11-22.

- Juwaheer, T. D. (2011), Gender bias in hotel guests' perceptions of service quality: an empirical investigation of hotels in Mauritius," E review of Tourism Research, Volume 9, Number 5, PP 164189. 
- Jysmä, E. (2012), The physical environment and its relevance to customer satisfaction in boutique hotels; Hotel Haven, Helsinki'Thesis submitted to the Haaga-Helia university of applied sciences.

- Kariru Antoneta Njeri Kariru, Aloo Charles (2014), Customers 'perceptions and expectations of service quality in hotels in western tourism circuit, Kenya,"Journal of Research in Hospitality, Tourism and Culture, Volume 2, Number 1, PP 1-12

- Kisang Ryu, H. H. (2010), Influence of physical environment on disconfirmation, customer satisfaction, and customer loyalty for first-time and repeat customers in upscale hotels," International CHRIE Conference-Refereed Track, PP 1-8.

- Kumar Babita, Banga Gagandeep and Thapar Jagriti (2008), 'An Assessment of Service Quality of Hotel Industry," A Refeered Quarterly Journal, Vol. 4, Issue 1, PP 13 - 30.

- Lund-Durlacher, P. D. (2011), The Lobby as a Living Room:What Interior Design Innovations and Products do Luxury Hotels Implement to Attract Guests to their Lobby?," Thesis submitted to Modul Venna University.

- Mackay, P. D., Petzer Daniel (2014), Dining atmospherics and food and service quality as predictors of customer satisfaction at sit-down hotels,"African Journal of Hospitality, Tourism and Leisure, Volume 3, Number 2, PP 1 - 14.

- Munir, M. M, Naqshbandi Muzamil (2011), Atmospheric Elements and Personality: Impact on Hotel Lobby Impressions," World Applied Science Journal, Volume 15, Number 6, PP 785-792.

- Rutkin, K. M. (2005), User preference of interior design elements in hotel lobby spaces," Thesis submitted to the University of Florida.

- Sakun Boon D. N. (2012), "Measuring Service Quality Dimensions: An Empirical Analysis of Thai," International Journal of Business Administration, PP 52-63.

- Sharma Chandrashekhar (2014), "A Service Quality Model Applied on Indian Hotel Industry to Measure the Level of Customer Satisfaction", International Journal of Science and Research, Volume 3, Number 3, PP 480-485

- Siddique Md. Nur-E-Alam, Akhter Mst. Momena, Abdullah Al Masum (2013), 'Service Quality of Five Star Hotels in Bangladesh: An Empirical Assessment" Asian Business Review, Volume 2, Number 2, PP 67 - 72

- Ubedullah Amjad Ali, Shaikh, N. R. (2011), Impact of service quality on customer satisfaction: evidences from the resturant industry in Pakisthan," Management and Marketing, Volume 9, No 2, PP 344-355.

- Yasir Shafiq, Shafiqque Imran (2013), Impact of Service Quality on Customer Satisfaction: A Study of Hotel Industry of Faisalabad, Pakistan," International Journal of Leadership and Organisational Studies, Volume 2, Number 2, PP 55-59. 
